\title{
焼却灰を用いた電解励泥処理に関する研究
}

\section{RESEARCH ON THE SEWAGE SLUDGE TREATMENT BY FLUORIDE ELECTROLYSIS USING INCINERATOR ASH}

\author{
大木宜章*・金井昌邦** \\ By Takaaki OKI and Masakuni KANAI
}

\begin{abstract}
Investing the effectiveness using sludge incinerator ash for sludge condition and its effective adding methods for improving dehydration in fluoride electrolysis sludge treatment, following items were clarified in this paper : 1) It is found that the sludge dehydration was improved in proportion to the addition of sludge incinerator ash ;2) But, generally sludge incinerator ash itself includes many fine particles with high specific gravity, which may plug filtration. Therefore, the surface reforming was required to improve the dispersibility of particulates. As a result of this, the dehydration (becomes better) in smaller adding volume than previous one; 3) Further, considering ionically the adhesion and combination of the organic fiberizing matters produced by electrolysis with sludge incinerator ash, timely change of addition time does not only decrease the amount of sludge incinerator ash but increases sludge dehydration. From these results, it was concluded that the utilization of the sludge incinerator ash for sewage sludge treatment by electrolysis is very useful.

Keywords : incinerator ash, sludge condition, improrving dehydration, electrolysis treatment
\end{abstract}

\section{1. 下水污泥焼却灰利用の基本的考察}

下水道普及率の上昇に伴い, 処理場から発生する污泥 の最終処分量は 61 年で 122 万 DS, tf と膨大な量になっ ている.この污泥の大半は脱水ケーキ性状であり, 陸上 および海面埋立等により最終処分されているが埋立処分 地には限度がある。 また投棄される污泥は親水性有機物 であり,含有される有機物や重金属の溶出が予想される. しかし，最終処分污泥の有効利用率 ${ }^{1)}$ は $17 \%(61$ 年度 の内訳は表一1 に示す）と低い. 表からこの実施状況は 脱水ケーキ性状による緑地利用が大部分を占めるが，近 年このような利用は大幅に減少し, コンポスト化に移行

\section{表一1 下水污泥の有効利用実施状況}

(S 61.4.1 S 62.3.31) (単位: 千 $\mathrm{m}^{2}$ )

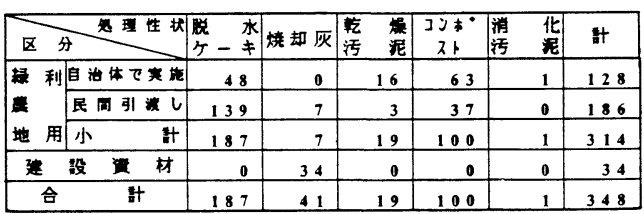

* 正会員 工博 日本大学助教授 生産工学部土木工学科 （宁275 習志野市泉町 1-2-1）

** 正会員 理・医博 イオン理化研究所 ( ₹240-01 神奈川県三浦郡葉山町一色 1750)
している. また最近の傾向として最終処分量の減量化を 計るべく污泥焼却が進んでいる.このため焼却灰の建設 資材への利用度合が増加し, 建設省, 日本下水道事業団 ${ }^{2)}$ を始め, 地方公共団体においても積極的に取り組まれ, 路床材, 土質改良材, 軽量骨材等の利用への種々の報告 がなされている.しかし亡゙の利用においても決定的方法 とは思われず，現在模索中といえる. その一方法として 本研究は焼却灰を污泥処理にフィードバックさせ, 污泥 処理調質剂としての利用を検討するものである. 一般に 污泥脱水促進の調質剂としての条件は

a) 比重: 污泥より比重が大きく, 懸濁させても 液面に浮遊しない.

b）粒 度：沈積しにくく分散性・懸濁性の良いこ 亡.

c）圧 縮 性：ケーキは多孔質かつ非圧縮性で沃過抵 抗が十分小さいこと.

d）不溶解性：化学的に安定し, 反応を起こさない. 可溶性塩類や有機物質および着色性不 純物が含有されないこと.

e) 親 和 性: 污泥固形分と親和性が良いこと.

f）安価であること.

等が挙げられ石灰, 無機凝集剂, ポリマー等が用いられ ているが，これら一部の凝集剂は高価であり，その代用 
物として焼却灰の利用を考えた。このような試みはわず かにアメリカ等で報告3)されているが沪過補助㓣とし て, 単に固形物量を増加させ沃過性の向上を計っている にすぎない。しかし電解処理污泥焼却灰には，污泥処理 で添加された凝集剛の鉄分, さらには $\mathrm{Ca}$ 等の無機物質 分，特に Fが含まれ，これらを再利用できる可能性も推 測される。したがって先に記した調質剤としての条件に 凝集または凝集補助剂として溶液中での凝結に有用な弗 化物および水酸化物重合体を形成する能力の有無が付け 加えられる.

これまでの実験から電解処理した污泥はこの性状が改 善(1),5)され，脱水性の向上 ${ }^{6 /}$ が計られ，処理污泥の再利用 にも有利と結論した。本研究でもこれら利点をもつ電解 法を用いることとした．このため電解処理污泥焼却灰の 物理化学的性状を明らかにし，調質剂としての有効性の 有無を沪過性の向上，ヶーキ含水率低下（発生污泥量の 減少）等により検討するものである.

\section{2. 実験方法および実験条件}

試料はS市下水処理場から採取した余剩污泥（以後原 污泥と記す）を電解処理（以後電解污泥と記す）して用 いた。なお，添加物質の量は原污泥の全蒸発残留物量を $100 \%$ として換算した。またその量は実験により異なる のでその都度 [\%] をもって明記する．

\section{（1）焼却灰作製方法}

初めに余㮃污泥に原污泥の全蒸発残留量に対し $\mathrm{FeCl}_{3}$ $15 \%, \mathrm{CaCO}_{3} 10 \%, \mathrm{CaF}_{2} 10 \%$ を添加し，污泥処理量 $25 l$ に対して総電流 $1.25 \mathrm{AH}, 3 \mathrm{~V}$ 以上, 1 時間処理した. 処理污泥はNY 100 メッシュ沃布にて脱水後, 焼却した. この焼却温度は污泥中の $\mathrm{Fe}$ 分の再使用を考慮し $900^{\circ} \mathrm{C}$ とした [この焼却温度 (約 $400 \sim 700^{\circ} \mathrm{C}$ ) で $\mathrm{FeCl}_{3}$ は $\mathrm{Fe}_{2} \mathrm{O}_{3}$ に変化する]. さらに焼却残差を粉砕し $74 \mu \mathrm{m}$ ふ るいにかけて試料として用いた。

\section{（2）脱水試験方法}

電解装置 $(25 l) \mathrm{Al}(+), \mathrm{Cu}(-)$ 極板を使用し，こ れまでの実験より求められた処理電流 $0.5 \mathrm{AH}, 1$ 時間 を基準として電解処理をした。この処理污泥をヌッチェ テスト装置により（沪過面積 $20 \mathrm{~cm}^{2}$, 真空度 $60 \mathrm{cmHg}$ ) 比抵抗值を求めた。

\section{3. 焼却灰の物理化学的性状の検討}

焼却灰の物理化学的性状は, 前記した必須条件の沪過 向上を計るために重要な因子であり,この分析を行った。

\section{（1）比重，粒度分布}

焼却灰の粒度分布は $74 \mu \mathrm{m}$ 通過試料を用い，コール ターカウンターで粒子個数（図一1）さらにふるい分け より重量百分率による粒度分布を求め検討した。図一1

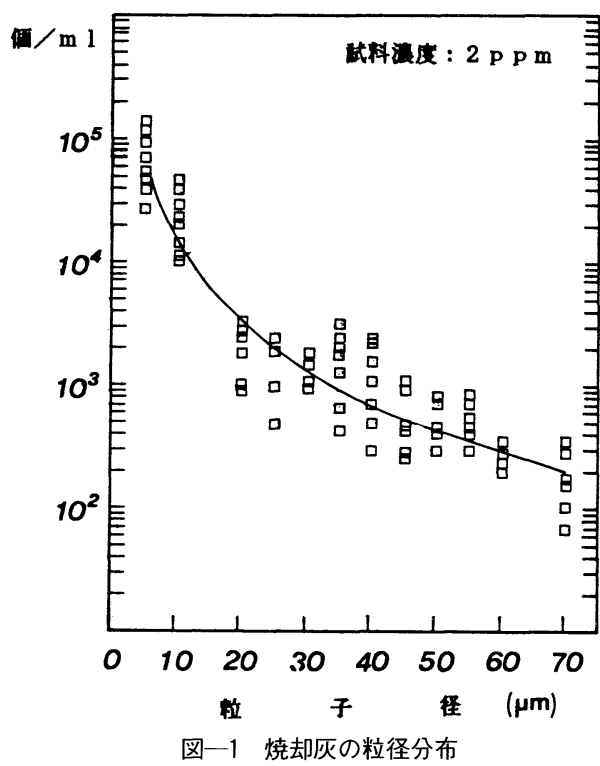

より焼却灰粒子の大部分（70\%）は $10 \mu \mathrm{m}$ 以下の微粒 子であると判明するが，粒子重量百分率による粒度分布 からこの $10 \mu \mathrm{m}$ 径以下の粒子はわずか全試料重量の 10 \% 以下である。すなわち試料重量に占める割合が少な く，しかも粒子数が多いことから微粒子が多量に含まれ ているといえる。一般に沪過剤はこの径が $40 〜 50 \mu \mathrm{m}$ を越えると沪過系内で沈降しやすく，沪過に役立つこと は少なく, $2 \mu \mathrm{m}$ 以下では沪過抵抗が大きく難沪過性に なる。なお比重は 2.55２.67で懸濁させても液面には 浮遊せず沈積しやすく,一般に分散性と懸濁性に欠ける.

\section{（2）X線解析による検討}

X線分析の測定条件は

TARGET; Cu(Ni Filter) TUBE; 40kV/20mA SLITS ; DS $1^{\circ}$ RS $3 \mathrm{SS}^{\circ} \quad$ SCAN speed ; $4 \mathrm{deg} / \mathrm{min}$ STEP/SAMPLING;0.2 DEG とした.

図一2 より焼却灰に含まれる物質は，大まかには電解 処理に添加した $\mathrm{CaF}_{2}, \mathrm{FeCl}_{3}, \mathrm{CaCO}_{3}$ の化合物として

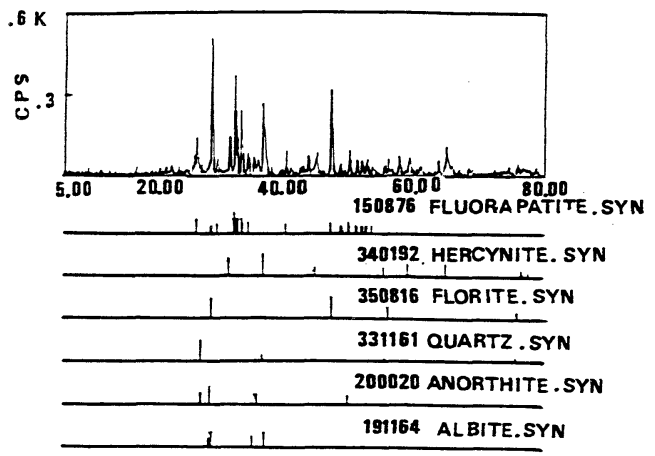

図一2 X 線解析結果 


\section{表一2 回折強度による含有物質の検討}

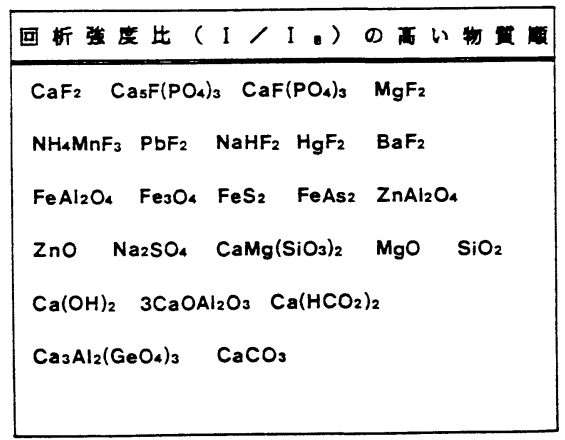

弗素化合物, 鉄化合物, さらに $\mathrm{SiO}_{2}, \mathrm{Ca}$ 塩, $\mathrm{Na}$ 塩が分 析される.この解析で $I / I_{0}$ (回折強度比) が高く現わ れている物質を表一 2 に示す。表より $\mathrm{CaF}_{2}$ は $I / I_{0}$ が一 番高く現われていることなどから $\mathrm{CaCO}_{3}$ も含め, これ らはリサイクルの可能性があると推測される. 特筆すべ き点は重金属類の弗化物化が多く認められる.すなわち 電気陰性度より物質結合は弗化物>酸化物 >塩化物の順 に安定度が高く，したがって弗化物化した重金属類は不 溶性物質となる．また原污泥では脱離水中にリン分が溶 出するためリンは原污泥試料にわずかに検出するが電解 処理污泥およびこの焼却灰では弗化アパタイトとして大 量に検出される.すなわち污泥中のリンは電解により $\mathrm{Ca}^{+}$と反応し, 弗化アパタイトとして不溶解物質となっ て存在する.したがって先の重金属類, リンも電解污泥 の焼却灰では安定化 (不溶解) 物質となっていることが 判明する。これらの性状より先の焼却灰に求められる調 質剂としての条件を考えると再使用の可能性は $\mathrm{CaF}_{2}$, $\mathrm{CaCO}_{3}$ が第一に挙げられるが, 分散性と懸濁性に欠け る. 不溶解性については弗化物化により安定度は高く, 水に添加しても溶解および着色は確認されない. 焼却灰 は物質分析からも疎水性が強く污泥固形分との親和性に 乏しいと思われ，先の分散性とともに調質剂としての短 所となりこの改質が必要と思われる.

\section{4. 污泥処理実験および検討}

\section{（1）焼却灰添加による沪過性の検討}

焼却灰の粒度は沪過性に重要な影響を与え， $37 \mu \mathrm{m}$ ふふ るい通過試料では微粒子が沪過閉塞を起こしやすく 150 $\mu \mathrm{m}$ 以上では早急に沈積し不透水層を形成，ともに比抵 抗值は極端に悪化した。最良の沪過性は $53 \mu \mathrm{m}$ ふるい 通過試料であったが, この粒度におけるふるい分け作業 は $74 \mu \mathrm{m}$ に比し $2 \sim 3$ 倍の労力を必要とし困難を極め た。したがって沪過性も良く容易に試料が採取できる $74 \mu \mathrm{m}$ ふふるい通過試料を用いることとした。この粒度灰 を使用し添加量変化させた沪過性を図一3に示す．図よ

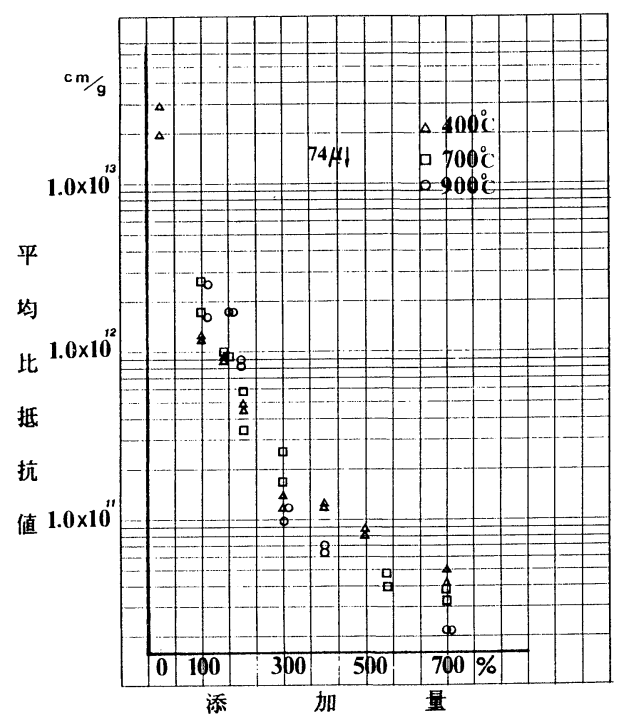

図一3 $74 \mu \mathrm{m}$ 以下の焼却灰を添加した結果

り焼却灰添加により沪過性は向上し, しかもその量が多 いほご良好な結果となる。このケーキ含水率は図一 4 に 示す. 焼却灰添加増量とともにケーキ含水率も著しく低 下し，圧搾脱水操作を行うと最終ケーキは $42 \sim 44 \%$ と なる。なお発生污泥量は添加した焼却灰量十污泥固形物 量と一致し，ほぼ全固形物量が捕獲回収されている。 以 上の結果より焼却灰は沪過性の向上, ケーキ含水率の低 下に有効之認められる. しかし, 短所としては通常污泥 処理に用いられる $\mathrm{FeCl}_{3}$ に対応する比抵抗値を得るに は発生污泥が多量にならざるを得ない。図一4からは明 確な変曲点は見出されないが, これまでの電解污泥処理 実験（ $\mathrm{FeCl}_{3} 15 \%$ 添加）における比抵抗值に近い 300 $\%$ を添加量の基準とし以後の実験を行った.

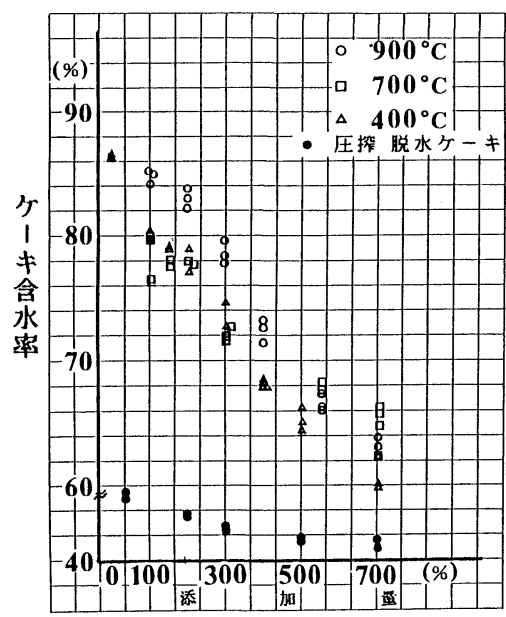

図一4 ヌッチェテストケーキ含有率 


\section{（2）焼却灰含有物のリサイクル効果}

焼却によりリサイクルできる添加剤は先のX線分析か ら高い $I / I_{0}$ 值を示した $\mathrm{CaF}_{2}$ さらに $\mathrm{CaCO}_{3}$ が挙げられ る.これらの物質は污泥安定剂 ${ }^{4}$ として添加され，特に $\mathrm{CaF}_{2}$ においては再使用が十分可能な結果を示してい る。そこで一度調質に使用した焼却灰をリ少イクルでき るかどうか検討した．結果は図一5に示す．図上り 1,2 回目の比抵抗值は上昇するもの, 2 回目以上のリサイク ル灰を使用した電解污泥の比抵抗はほぼ一定した值とな る. また電解処理時の電圧は酸化鉄の分解電圧より高く, $\mathrm{Fe}^{+}$が遊離するがその值は分析から 6 8 ppm（リサイ クル灰の $2 \mathrm{~N}-\mathrm{HCl}$ 抽出では $\mathrm{Fe}^{+}$は 0 回目 $1000 \mathrm{ppm}, 1$ 回目 $500 \mathrm{ppm}, 2$ 回目 $100 \mathrm{ppm}$ であった）と低く，あま り凝集効果は期待されず，沪過性のわずかな低下の原因 は焼却灰の性状変化によるものと推測される。この性状 変化を視的観察すると焼却灰は, 黒色 $\rightarrow$ 茶褐色 $\rightarrow$ 赤褐色 に変化する。すすなわち当初焼却灰は難燃性有機物が $\mathrm{Fe}$, あるいはその他の添加物等との結合物質を作り，底泥と 同じく反射光の皆無な物質となり黒色を呈していると思 われる。この難燃性有機物がサイクルを増すごとに燃焼 され，鉄酸化物の赤褐色を帯び，しかも強度的にもろく なる傾向を示した。これらのことから難燃性有機物は不 定形の極性結晶となり粉砕しにくいが，使用度合が進む につれこの極性結合物質がガラスや氷のような分極性分 子の集合体となるためにもろくなると推測される。なお 赤褐色は, $\mathrm{Fe}$ 分が $\gamma-\mathrm{Fe}_{2} \mathrm{O}_{3}$ から $\alpha-\mathrm{Fe}_{2} \mathrm{O}_{3}$ (ベンガラ) に変化するためで, この $\alpha-\mathrm{Fe}_{2} \mathrm{O}_{3}$ は微粒子（約 $0.1 \mu \mathrm{m}$ 以下）である. また $\alpha-\mathrm{Fe}_{2} \mathrm{O}_{3}$ の微粒子は使用度合によ り増加し（1 サイクル目の焼却灰は 0 サイクル焼却灰に 比し, $37 \mu \mathrm{m}$ 以下の粒子重量分布は $10 \%$ から $30 \%$ に 増加），したがって比抵抗值が高くなる原因であると思 われる．以上結果から単に焼却灰のみ添加する污泥処理

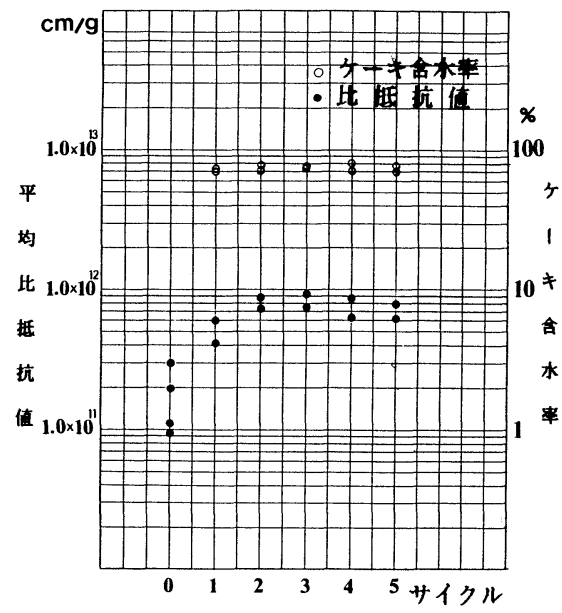

図一5 焼却灰 $\left(900^{\circ} \mathrm{C}, 300 \%\right)$ 再利用の効果
では，沃過性向上に限界があり何らかの工夫が必要であ ると思われる。

\section{（3）焼却灰の分散性改良に対する検討}

前記したごとく焼却灰は比重の高さから分散性，懸濁 性に欠け，さらに物質性状変化から疎水性を帯びるので 親和性に乏しい。したがって污泥含有物との付着および 結合等の物理化学作用を起こす度合は少なく，沃過性状 の改質に十分役立っているとは思えない。しかし分散性 の良い微粒子にすると沪過閉塞を起こす矛盾が生ずる. これらのことを加味し，良好な分散を得る一方法として 粉体の表面改質を取り上げた。すなわち分散性の良くな い無機粉体の表面にゾル，ゲルあるいはその他の有機物 を付着させ，親和性の向上を計るよう焼却灰の表面処理 を行うこととした。本実験ではコーティング剤の価格さ らには操作のしやすさ，表面改質焼却灰の沈降時間等を 考慮し，アルギン酸ナトリウムを使用することとした。 なお焼却灰のコーティング方法については種々検討し， 沃過系にゲル化粒子の不透水層を形成しにくいアルギン 酸ナトリウム溶液 1 に対し焼却灰 1 (重量比率) で混合 し強攪汼する方法を用いた。 なおゲル化粒子のためか高 濃度ほど測定值にばらつきが多く帯状に結果を図一6に 示した。

図よりアルギン酸ナトリウム濃度 $12.5 \mathrm{mg} / \mathrm{m} l$ が最良 の結果を示した。なお操作はコーティング濃度が高い之 粘性が強く混合しにくい，しかも粒子がアルギン酸過剩 となるためか沪過系にゲル化粒子の不透層を形成し沪過 性は低下する。このコーティング濃度を用いると $150 \%$ 以上の添加量で比抵抗值は約 $1 \times 10^{10} \mathrm{~cm} / \mathrm{g}$ となり，図 一3における $700 \%$ 添加時とほぼ同様な值となる。また 焼却灰基準添加量 $300 \%$ 值を得るには $1 / 5$ の $50 \%$ の添 加量で良い結果を示した。すなわち焼却灰の改質は分散 性の向上と同時に混合操作において，沪過閉塞を起こす

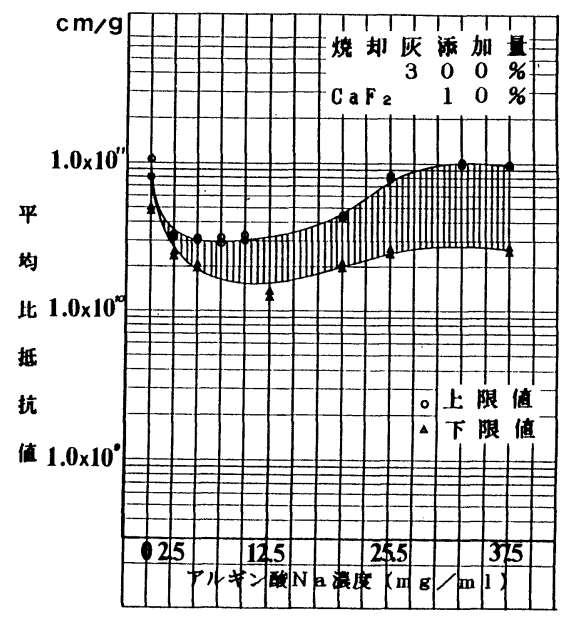

図一6 焼却灰コーティング濃度変化による脱水効果 
ような微粒子が粗粒子に付着結合するため良好な脱水が 計られると推測される. しかしアルギン酸ナトリウムは 無機凝集剤に比し高価でしかも複雑な表面改質操作を必 要とする.また発生ケーキもアルギン酸によるゲル化の 影響もあって高い含水率となり,これらも含め今後の検 討課題である.

\section{5. 電解生成物を生かした沪過性の改善および 検討}

これまで焼却灰を調質剤として考え，この条件に適合 する種々の方法で検討改良を試みてきた。しかし焼却灰 は，あくまで焼却灰であり，その物理化学的性状の範囲 に限られるためか沪過性の向上効果は見出されるが限度 があり，また発生污泥も多量にならざるを得ない，軽減 の一方法として図一1 上り焼却灰粒子の大半を占める難 沪過性微粒子をいかに捕捉して凝集するかにある。この ため電解処理した污泥の特徵ある性状変化 ${ }^{5 /, 6)}$ を利用し, この電解污泥により焼却灰の捕捉を計ることにした。

\section{（1）電解生成物と焼却灰の付着結合の検討}

電解に上り生成される物質の経時性状変化は過去に発 表したが，これによると電解生成物は繊維となり，さら に網目状のマクロな物質に変化する。 またこの繊維物質 は生成の過程で大きな分子全体に電荷が分布し，その結 果電荷した部分と無電荷部分に分かれる ${ }^{5,6)}$. すなわち この電荷部分に閉塞を起こす微細な粒子を付着結合させ れば沃過性の改善がなされると推測される。結果は図一 7 となる。

図より各焼却灰量とも電解開始 10４0 分後添加によ り比抵抗值は低下傾向を示すが，添加量により改善され る度合が異なる。これは電解生成物之焼却灰量の割合が 影響しているものと思われるが，しかしいずれの添加量

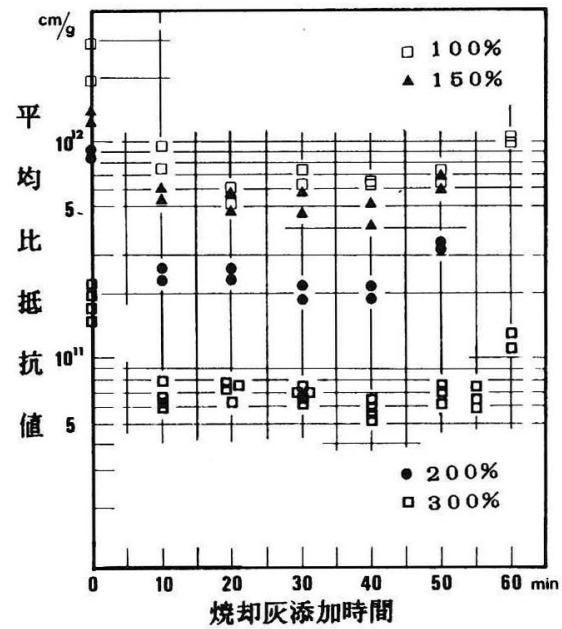

図一7 焼却灰添加時間変化による比抵抗値の相違
でも繊維物質への付着結合が大きく寄与していると推定 される.視的観察 (写真一1，2）に上れば，電解早期の 添加では焼却灰が電解生成物に混入し一体化した物質を 形成している. 電解開始 40 分後に添加する之十分に生 成した電解生成物にオーバーラップするように焼却灰が 付着し,さらにこの一部繊維は焼却灰に架橋して一体化 した物質となっている。 なお基礎的実験引によると電解 有機物の生成は, 無機物に比ベスムーズに進行し, 有機, 無機混合物では無機物をこの電解有機物に取り込んで一 体化した電解生成物を形成することが判明した．しかし 初めに電解有機物を生成させてから無機物を添加する と，より早く一体化した電解生成物となることが観測さ れた。

すなわちこの基礎実験結果からも沪過性の向上には繊 維物質が十分に生成された時点で焼却灰を添加させるべ きであり，この時期はほぼ 40 分後が適当であると思わ れる. しかしこれでは電解処理 0 40 分間 $\mathrm{F}^{-}$イオンの 作用がなく, 前記した有機物は十分な電解生成物とはな らず，したがって電解開始時に $\mathrm{CaF}_{2}$ を添加するか，ま たは焼却灰一部をあらかじめ加え残りを 40 分に添加さ せる必要がある。

\section{（2）電解生成物強化による検討}

これまで焼却灰のみ添加させ, その沪過性を検討して

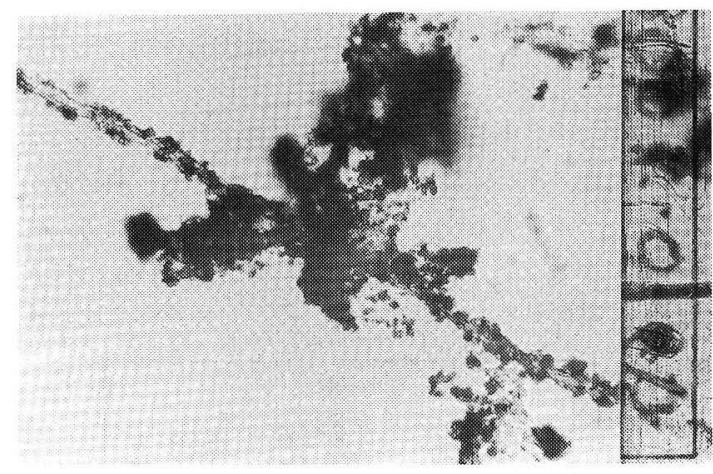

写真一1 0 分後添加による電解污泥の性状 $(\times 400)$

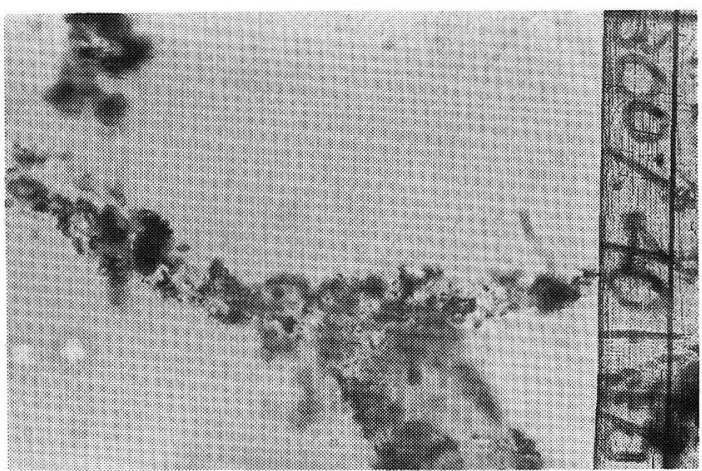

写真一2 40 分後添加による電解污泥の性状 $(\times 400)$ 
きたが,さらに沪過性の向上, 発生污泥量の軽減を計る ためには電解生成物をより多くマクロ化すべきである. このために一般的に污泥処理に用いられている $\mathrm{FeCl}_{3}$ を添加し，凝集をさらに促進させ焼却灰の軽減と効率的 な脱水条件を検討した。結果は図一8に示す。なお焼却 灰は先の結果から 40 分に添加した. 添加 0 分時におけ る值も比較のために加えた. 図より凝集剂添加により各 焼却灰量で沪過性が大幅に改善される。このケーキ含水 率は図一 4 の各添加量における含水率より 2 - 3 \% 低下 した.なお焼却灰のみ添加での比抵抗（図一3）は添加 される焼却灰量により大きな值の差を生じたが，この実 験では $\mathrm{FeCl}_{3}$ を $4 \%$ 以上添加すれば焼却灰量の変化に よる比抵抗值の差は少ない結果を示した.

これまで污泥の沃過性は焼却灰量の多少に左右されや すいと結論したが，凝集を強化させ電解生成物の増加を 計ることが沃過に重要な影響を与えていることが判明し た（たとえば焼却灰 $80 \%, \mathrm{FeCl}_{3} 8 \%$ では前記結果図 一-3の $300 \%$ とほぼ同值となり，また $\mathrm{FeCl}_{3}$ の存在下 でも焼却灰を 0 分に添加した值とでは大幅に改善され る).

なお図から焼却灰量 80２00％で值の差は少なく， また0 分添加と比較しても十分な沪過性であることから も，この添加量は 80 \% 以下で良いと判明する.なおこ の視的観察は写真一 3 となる.

污泥中のタンパク質を主とした有機物質の物理化学的 性質は次のようにいえる.

有機化合物は電気的に不活性のものが多いが水等に溶 解して電離すると電極反応を示す。これは水溶液溶媒中 に分離したコロイドや，粒子が带電する結果である，す なわちタンパク質は $\mathrm{COOH}, \mathrm{NH}_{3}, \mathrm{H}$ 基の離合反応によ り粒子が電荷をもつこととなり, そのため凝集作用に重

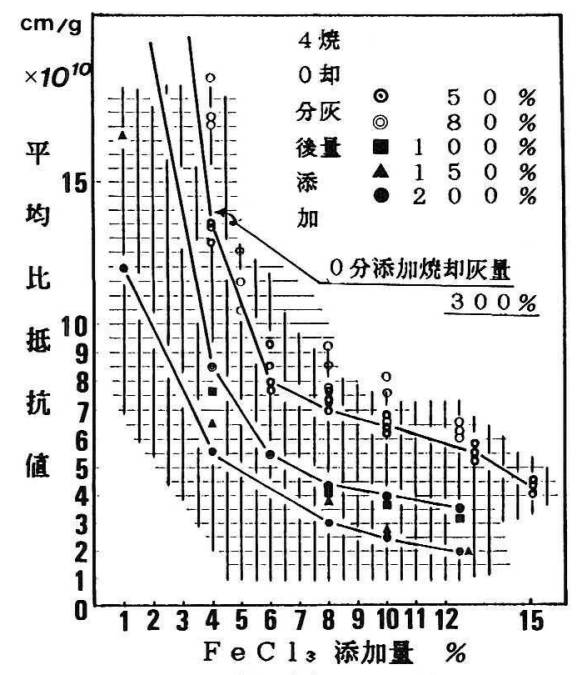

図一 8 凝集㘊量変化による比抵抗値

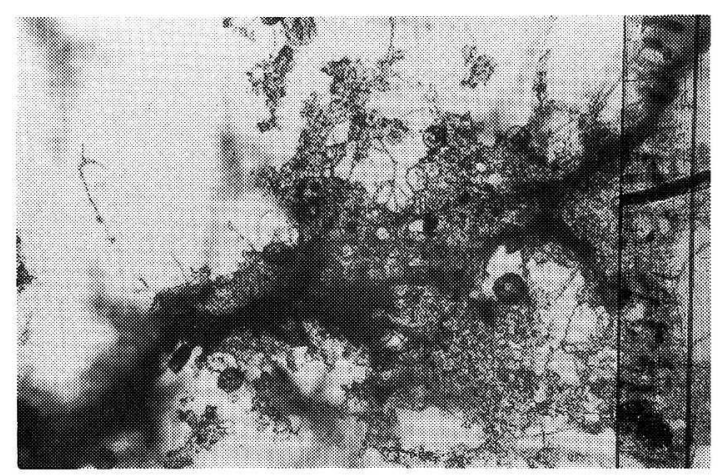

写真一3 焼却灰と $\mathrm{FeCl}_{3}$ を添加した電解污泥の性状 $(\times 100)$

要な要因を作る.この物質はペプチド結合反応の繰り返 しでマクロな分子が作られるといわれる．この分子(重 合体）は単一鎖状の高分子ではなく，2つまたは 3 つの 鎖が水素結合を主として，ジスルフィード橋，S-S お よび金属イオン介在等により架橋結合をし，三次元的な 結合となる．この重合体を作る反応により生成瀻維化し たものは元に戻ることなく（大きな分子全体に電荷が分 布するため) 不溶解性物となる.ここでの反応は共有結 合するばかりでなく，水素結合，イオン結合も相互作用 すると考えられる．これら作用により電解生成繊維とな り, 図一9(a) のような電荷が分布する.この部分に分 極ポテンシャルを打ち消し 0 に近付くように無機物が オーバーラップする付着結合図一 $9(\mathrm{~b})$ が起こる7).こ の効果が添加される焼却灰量の軽減に寄与していると思 わ机る。

\section{（3）電解処理污泥性状の検討}

前記処理污泥の性状を脱水圧力変化（真空度 10６0 $\mathrm{cmHg}$ ）関係から求められる圧縮係数により検討する. この圧縮係数は圧縮性の低い無機污泥では 1 以下とな り, 有機污泥では 1 以上の値となる. 結果を図一10に 示す。なお図中での原污泥とは未電解試料である。

図から原污泥では付着結合しない焼却灰が沪過系内で 急速に沈降し層を形成するため，むしろ焼却灰を沪過す る現象となりこの係数は無機污泥の性状を示す。すなわ ち焼却灰添加時間により処理污泥は有機または無機物を 主体とした污泥に近い性状を示すことが推測されるが,

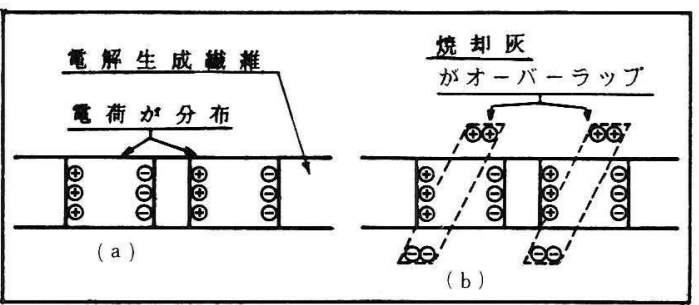

図一9 電解生成緎維と焼却灰の付着結合状態 


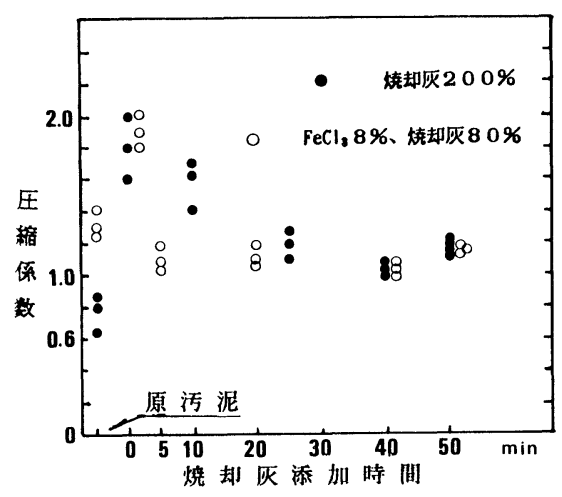

図一10 添加時間による圧縮係数の変化

これまで各実験から求められた条件を用いて処理した污 泥の係数は 1 に近い值となる. なお無機凝集剤による凝 集物は高分子凝集剤による粗大フロックに比し小さいが 含水率は低く強度の強い性状を示す. しかし沪過脱水性 の向上にはフロックの大きさにも関係し, 両者の併用に よってそれぞれの長所を生かすことが良好な沪過性を可 能とすることからも, 圧縮係数が 1 に近い電解処理污泥 は比較的シアリングに強い圧縮性の低い污泥に変化し, 沪過性の向上に寄与していると判断される.

\section{6. 総 括}

下水污泥は環境污染防止, 衛生的また利用上の問題 ${ }^{81}$ 加悪臭, 殺菌, 分解, 重金属, 污泥品質の変化等未解 決な点が多く, このため建設資材等への再利用技術など は確立されていない. しかし電解污泥では重金属, 殺菌, 有機物分解の問題等はすでに解決ずみであり, 本研究は 主に焼却灰の調質剂としての利用を検討し, 次の事項を 明らかにした。

（1）焼却灰は沪過閉塞を起こすような微粒子が多 く, 比重も高い疎水性物質である. したがって污泥との 親和性に乏しく, 沪過系内での沈降が早いので污泥含有 物との接触が限定され, 結合および反応は起こりにくい.

（2）電解処理した污泥の焼却灰はX線分析より重金 属類は弗化物となり再溶解のない安定物質となってい る.またリン分も難溶解性の弗化リン灰石として存在す る.さらに污泥処理に用いた薬剤, $\mathrm{CaF}_{2}, \mathrm{CaCO}_{3}$ は焼 却灰中に存在し, 污泥処理時に再度添加する必要はない. なお $\mathrm{Fe}^{3+}$ 分については電解処理における電圧値 (分解 電圧以上）でも微量にしか検出されず，この効果は期待 できない。

（３）焼却灰添加により沪過性は良好となるが，この 量は原污泥固形分の数倍を必要とし, したがって発生污 泥量は多くなる. また焼却灰のリサイクルは微粒子の占 める割合が増加することによって沪過性の低下は免れな
い.

（４）分散性向上のための表面改質は沪過性を良好に するが,この改質のためには複雑な操作を必要とする.

（5）沪過性の向上, さらに焼却灰の減少には電解生 成物との付着, 結合の強化を計るべきである. 電解処理 では有機物の電解反応が骨格となり,これに $\mathrm{CaF}_{2}$, $\mathrm{FeCl}_{3}$ を用いた $\mathrm{Ca}^{2+}, \mathrm{Fe}^{3+}$ の生成反応が付加される. これら $\mathrm{Ca}^{2+}, \mathrm{Fe}^{3+}$ などの多価イオンはコロイド物質の 凝集を促進させ, タンパク質等の有機物間の架橋を形成 する.このような構造変化は電解エネルギーを得て自己 整形を進め, さらに強力な瀻維状の生成物を作る. した がってこの電解によりすでに脱水性状の向上を計ること ができるが，焼却灰をさらに添加すると電荷効果を伴っ た生成繊維部分にオーバーラップするように焼却灰が付 着され一体化するために少量でも有効に作用し, 大幅な 沃過性向上が期待できる.

（6）電解処理污泥は無機さらに有機物が一体となっ た凝集物を作るので有機・無機物の脱水長所をもつ.す なわち無機凝集剂による凝集物は有機凝集剤による粗大 フロックに比し相対的に小さいが緻密で水分の入る余地 が少ないため含水率が低く, 強度の強い性状となる. し かし沃過脱水に要する時間はフロックの大きさと密接に 関係するので, 両者の併用による相乗効果によって, そ れぞれの長所を生かすことができる.このような性状変 化は視的観察および圧縮係数からも立証される.

これらの結果から污泥処理に焼却灰を用いることは沪 過性を向上させるために有効であり, 焼却灰の再利用方 法として十分に活用されるべきだと思われる．最後に本 試験に際しご協力いただきました卒業研究学生諸氏に謝 意を表します。

\section{参 考 文 献}

1）下水污泥の建設資材としての利用法：建設省土木研究所, 1987.

2）建設省都市局下水道部：日本の下水道, 下水道協会, pp. 226 227, 1988.

3) Micale, F. J. : Wastewater Research Riv, Mechanism for ash assisted sludge dewatering, 1976.

4) 大木宜章ほか：污泥処分の環境影響に対する安全性の検 討, 下水道協会誌, Vol. 120, No. 228, pp. 45 52, 1983.

5）大木宜章ほか：電解による污泥脱水性の改善に関する研 究, 下水道協会誌, Vol.119, No.220, pp.61 69, 1982.

6）大木宜章ほか：電解法を用いた污泥脱水の基礎実験, 下 水道協会誌, Vol.119, No. 221, pp. 71 79, 1982.

7) Kanai, M. and Mimori, T. : J. JAP. Optical Study of the Nacereous Layer of Shell, Vol.115, No. 8, 1976.

8) 大小宜章ほか：電解による污泥処理とその利用に関する 研究, 土木学会論文集, 第 369 号 / II -5, pp. 261 269, 1986.

(1989.11.22 - 受付) 